\section{Potential roles for tenascin in (very) early diagnosis and treatment of rheumatoid arthritis}

We read the interesting article by Aungier et al suggesting that targeting proinflammatory signals from the C-terminal fibrinogenlike globe domain (FBG) of tenascin-C (TNC) might provide a viable strategy to treat rheumatoid arthritis (RA). ${ }^{1}$

The present story and possible developments are really interesting and might link to other recent evidences concerning the same argument.

We described for the first time in 1992 the distribution of TNC in normal and pathological synovial tissues from patients with RA and osteoarthritis (OA) by indirect immunofluorescence using specific monoclonal antibodies. ${ }^{2}$

Tenascin was found in normal synovium just beneath the whole lining cell layer; however, a higher density and spreading pattern of distribution was observed in RA and OA sections, but the possible meaning was unclear at that time.

Soon after, these early data were confirmed by others, and several investigations added that TNC levels were elevated in both RA cartilage and synovium and the T-C soluble form was detectable in synovial fluids of patients with RA. ${ }^{3}$ Additionally, serum TNC levels were found to correlate with joint erosions in patients with RA. ${ }^{4}$

Interestingly, TNC stimulates inflammation by inducing de novo cytokine synthesis via activation of toll-like receptor 4 (TLR4), modulating cytokine synthesis post-transcriptionally via induction of microRNAs and regulating adaptive immunity by driving Th17 cell polarisation. ${ }^{56}$ In murine models of arthritis, TNC expression is required to maintain chronic joint inflammation and, of note, the FBG of TNC is arthritogenic following its intra-articular injection.

Here, the story offers important aspects.

Generally, anticitrullinated protein antibodies (ACPAs) are wellestablished markers for the diagnosis of RA, appearing before evident clinical symptoms and correlating with a poor prognosis and progressive joint destruction. ${ }^{8}$

However, very few molecules recognised by ACPA have been demonstrated in the joint, epitope-mapped, antigen specificity confirmed and evaluated in independent large cohorts. ${ }^{8}$

Among these, the most important recent TNC-related discovery was that a citrullinated peptide from the FBG domain of TNC (cTNC5) was detected in RA synovial fluids, and surprisingly antibodies to cyclic peptides containing citrullinated sites again from the FBG domain were found in both pre-RA and RA sera. ${ }^{9}$

In particular, the autoantibody response to the FBG immunodominant cTNC5 peptide was analysed in 101 pre-RA sera (median 7 years before disease onset) and two large independent RA cohorts. Interestingly, $18 \%$ of pre-RA sera, and in $47 \%$ and $51 \%$ of RA cohorts were found positive with a specificity of $98 \%$ compared with healthy controls and patients with OA.

In addition, FBG domain cTNC5 antibody levels were found the highest in the whole anti-CCP2 antibody-positive subgroup and even $4.9 \%$ of the patients with RA within the anti-CCP2 antibodynegative group were also anti-cTNC5 ACPA-positive. Therefore, the study suggested that the FBG domain of TNC may be important in both the aetiology and pathogenesis of RA.

The actual study of Aungier et al shows that monoclonal antibodies recognising the FBG of TNC neutralise the FBG activation of TLR4 and therefore inhibit cytokine release by RA synovial cells and prevent disease progression and tissue destruction during collageninduced arthritis.

These results might really represent a new approach for (very) early RA therapy, by targeting early changes in the synovial microenvironment, especially in ACPA-positive patients.
In conclusion, testing the presence of anti-FBG cTNC in the sera of patients with early synovitis might help in discovering patients potentially developing RA, and might offer the chance of therapeutically targeting from the beginning the same FBG TNC domain with specific monoclonal antibodies.

This approach might block proinflammatory/immune signals from the extracellular matrix proteins (ie, tenascin) inside the synovial tissue, and from the beginning, as in a previous paper also some authors of the present study already recently tested and discussed. ${ }^{10}$

We agree with the authors that, on the light of these recent achievements, further explorations about potential roles of TNC in clinical practice for (very) early diagnosis and treatment of RA.

\section{Maurizio Cutolo ๑ , Stefano Soldano, Sabrina Paolino}

Research Laboratories and Academic Division of Rheumatology, Postgraduate School of Rheumatology, Department of Internal Medicine, University of Genova, Polyclinic Hospital San Martino Genova, Genova, Italy

Correspondence to Professor Maurizio Cutolo, Research Laboratories and Academic Division of Rheumatology, Postgraduate School of Rheumatology, Department of Internal Medicine, University of Geneva, Polyclinic Hospital San Martino Genova, Genova 16132, Italy; mcutolo@unige.it

\section{Handling editor Josef S Smolen}

Funding The authors have not declared a specific grant for this research from any funding agency in the public, commercial or not-for-profit sectors.

Competing interests None declared.

Patient consent for publication Not required.

Provenance and peer review Not commissioned; internally peer reviewed.

(c) Author(s) (or their employer(s)) 2019. No commercial re-use. See rights and permissions. Published by BMJ.

\section{Check for updates}

To cite Cutolo M, Soldano S, Paolino S. Ann Rheum Dis 2020;79:e42.

Received 12 January 2019

Accepted 20 January 2019

Published Online First 1 February 2019

\section{SLinked}

- http://dx.doi.org/10.1136/annrheumdis-2019-215108

Ann Rheum Dis 2020;79:e42. doi:10.1136/annrheumdis-2019-215063

\section{ORCID iD}

Maurizio Cutolo http://orcid.org/0000-0002-5396-0932

\section{REFERENCES}

1 Aungier SR, Cartwright AJ, Schwenzer A, et al. Targeting early changes in the synovial microenvironment: a new class of immunomodulatory therapy? Ann Rheum Dis 2019;78:186-91.

2 Cutolo M, Picasso M, Ponassi M, et al. Tenascin and fibronectin distribution in human normal and pathological synovium. J Rheumato/ 1992;19:1439-47.

3 Chevalier X, Groult N, Larget-Piet B, et al. Tenascin distribution in articular cartilage from normal subjects and from patients with osteoarthritis and rheumatoid arthritis. Arthritis Rheum 1994;37:1013-22.

4 Page $\mathrm{TH}$, Charles PJ, Piccinini AM, et al. Raised circulating tenascin-C in rheumatoid arthritis. Arthritis Res Ther 2012;14.

5 Midwood K, Sacre S, Piccinini AM, et al. Tenascin-C is an endogenous activator of Toll-like receptor 4 that is essential for maintaining inflammation in arthritic joint disease. $\mathrm{Na}$ Med 2009;15:774-80

6 Ruhmann M, Piccinini AM, Kong PL, et al. Endogenous activation of adaptive immunity: tenascin- $C$ drives interleukin-17 synthesis in murine arthritic joint disease. Arthritis Rheum 2012:64:2179-90.

7 Midwood KS, Orend G. The role of tenascin-C in tissue injury and tumorigenesis. J Cell Commun Signal 2009;3:287-310.

8 Wegner N, Lundberg K, Kinloch A, et al. Autoimmunity to specific citrullinated proteins gives the first clues to the etiology of rheumatoid arthritis. Immunol Rev 2010;233:34-54 
9 Schwenzer A, Jiang X, Mikuls TR, et al. Identification of an immunodominant peptide from citrullinated tenascin- $C$ as a major target for autoantibodies in rheumatoid arthritis. Ann Rheum Dis 2016;75:1876-83.
10 Raza K, Schwenzer A, Juarez M, et al. Detection of antibodies to citrullinated tenascin-C in patients with early synovitis is associated with the development of rheumatoid arthritis. RMD Open 2016;2:e00318. 